\title{
A CONTRIBUTION TO A EUROPEAN STRATEGY FOR THE WELL-BEING OF CITIZENS IN THE FACE OF AUTOMATION
}

\section{Una contribución a la estrategia europea para el bienestar de los ciudadanos frente a la automatización}

\author{
Máximo Plo Seco \\ Cultural Infusion \\ E-mail: maximoplo@gmail.com
}

Author

(1) Abstract

This article investigates the current and expected impact of automation technology in the well-being of European citizens. First, we explore the technical, social and economic factors that determine technological progress and the implementation of the new technologies. Second, we review the expected impact of automation on employment. Finally, we assess the impact that automation will have on the well-being of European citizens in light of the two first sections. To this end, we draw on the expected asymmetrical impact of automation in people with different education levels and on current inequality trends. Throughout the article, we use a normative approach, prescribing what European policy makers should take into account in light of our findings. We find that it is unclear what the net effect of technology on employment will be, but automation of non-routine manual and cognitive tasks will displace a significant percentage of workers. We find that current trends of increasing inequalities will intensify due to the fact that automation will affect more low-skilled workers. We find that the current institutional design of the European Union is unfit to tackle educational and social protection challenges. We can therefore expect social resistance to technological progress and political instability in the years to come.

Este artículo aborda el impacto actual y futuro de la automatización tecnológica en el bienestar de los ciudadanos europeos. En primer lugar, se exploran los factores técnicos, sociales y económicos que determinan el progreso tecnológico y la implementación de las nuevas tecnologías. En segundo lugar, se revisa el impacto de la automatización sobre el empleo. Finalmente, se examina el impacto que la automatización tendrá en el bienestar de los ciudadanos europeos a la vista de lo analizado en las dos anteriores secciones. Con esta finalidad, nos basamos en el impacto asimétrico esperado de la automatización en personas con diferentes niveles de educación y en las tendencias actuales de desigualdad. A lo largo del artículo, utilizamos un enfoque normativo, prescribiendo lo que los responsables politicos europeos deben tener en cuenta a la luz de nuestros hallazgos. Encontramos que no está claro cuál será el efecto neto de la tecnología en el empleo, pero la automatización de las tareas manuales y cognitivas no rutinarias desplazará a un porcentaje significativo de trabajadores. Encontramos que las tendencias actuales de aumento de las desigualdades se intensificarán debido al hecho de que la automatización afectará más a trabajadores poco calificados. Encontramos que el diseño institucional actual de la Unión Europea no es apto para abordar los desafíos educativos y de 
protección social. Por lo tanto, podemos esperar resistencia social al progreso tecnológico e inestabilidad política en los años venideros.

technological unemployment; well-being; European Union

desempleo tecnológico; bienestar; Unión Europea

Key words

Received: 25/03/2020. Accepted: 17/05/2020

\section{Introduction}

The financial and economic crisis was a blow for the European project. For the first time, since 2010, more people tended not to trust than to trust the European Union. As of 2016, this gap was 22\% (European Parliament [EP], 2016).

We have also been seeing a secular increase in inequalities ${ }^{1}$ of a considerable magnitude. The GINI dataset finds a steady increase in inequalities for EU-15² countries from 1985 to 2009, amounting to an average of 25\% inequality increase. The European Union and the OECD Income Distribution Dataset use poverty rates ${ }^{3}$ to put an emphasis on the lowest tale of the income distribution. The rate of income poverty for EU-9 4 countries rose from $13 \%$ in 1985 to $18 \%$ in 2012 , a $38 \%$ increase.

Growing mistrust towards the European project and growing inequalities are the starting point of this article, which seeks to understand the impact that automation technology will have on inequalities and the well-being of citizens in the European Union. It then reflects on what the European institutions should do about it, assuming either that citizen wellbeing is a goal of policy makers or that increasing inequalities will undermine public support for the European project.

The well-being of citizens is becoming increasingly popular with initiatives such as the Better Life Initiative of the OECD. Measuring well-being is a subjective task, and that is the reason why economists have traditionally relied on more objective measures such as the GDP, which even if also subjective, it is still grounded on a lot of empirical research. However, it is important that our societies strive for a maximization of social welfare and not just neutral economic and technical progress.

1 For further information see OECD reports Growing Unequal (2008), Divided We Stand (2011) and In It Together (2015); Joseph Stiglitz's The Price of Inequality: How Today's Divided Society Endangers Our Future (2012), Thomas Piketty's Capital in the 21st Century (2014) and Tony Atkinson's Inequality, What can be done? (2015).

2 Belgium, Bulgaria, Czech Republic, Denmark, Estonia, Germany, Italy, Latvia, Lithuania, Netherlands, Poland, Slovakia, Spain, Sweden and UK.

3 Measured as percentage of the population living in households with an income below $60 \%$ of the national median household income.

4 Denmark, Finland, Germany, Greece, Italy, Luxembourg, Netherlands, Sweden and the UK. 
Inequalities are a hurdle to well-being due to several reasons. In the first place, it has been shown that income provides utility depending on what others have (Easterlin, 1974; Stiglitz, 2012, p. 189). Secondly, empirical studies also show that income has a logarithmic effect on subjective well-being (Stevenson \& Wolfers, 2008). This means that, ceteris paribus, for the same increase in happiness, you need the same percentage increase in income. Therefore, the same increase in income has a higher impact on the well-being of those at the lower end of the distribution. Finally, social inequalities have negative consequences in the health of individuals (Marmot et al., 2010).

These points prove that an unequal society fails to maximize well-being in three ways. First, it disproportionately increases the malaise of those at the lower end of the distribution because of their relative position. Second, it fails to efficiently maximize welfare across the population by redistributing income from the wealthy to the poor. Thirdly, it does not take action to prevent premature deaths and health issues associated with inequality ${ }^{5}$.

Technological change is a constant of human development. Throughout history, our ancestors have made inventions which have contributed to the betterment of life for all the society. This work provides a glimpse of whether this trend will continue in the future or not.

The insights derived from this research are intended to serve as guidance for policy making. For this reason, we can find throughout this work references to the European Union's policies, strategies or recommendations to member states regarding issues such as health care, pensions, social protection or education.

We acknowledge that this work is limited because it does not analyze other megatrends that will be decisive in the future. For instance, emerging markets are growing exponentially. Whereas $95 \%$ of the Fortune Global 500 — world's largest companies - were from developed countries, by 2025 it is forecasted that more than $50 \%$ will be from emerging economies (Dobbs, Manyika, \& Woetzel, 2015, p. 10). In 2013, 60\% of the world population lived in countries with fertility below the replacement rate (p. 12). These are just two examples of many that are transforming the world. Our work will only focus on automation with only small references to other trends that we are experiencing.

To accomplish these tasks, we begin in the first chapter by analyzing the factors that determine technological progress and its adoption. The fast pace of inventions will be confronted with the many social and economic obstacles to their adoption. In the second chapter we investigate the impact that automation will have in the labor markets. We begin by analyzing the nature of work and which tasks are automated, confronting current automation with historical experiences. We then turn to analyze all the evidence that suggests that technology will be a substitute of labor and the evidence that suggests that there will be increased employment in the future. We end the chapter by reviewing the existing literature forecasting the impact of technology on employment. In the third and final chapter, we examine the social consequences of automation in terms of education and well-being. We explore what the most demanded skills of the future will be and how the European Union is responding to this need. We acknowledge the difficulties of education system reform. We then analyze

5 It has been calculated that in England, the people that die every year due to health inequalities could have enjoyed between 1.3 and 2.5 million extra years of life (Marmot et al., 2010, p. 9). 
what the impact on employment will be in terms of level of education and what the expected investment should be to retrain the workforce.

In short, the goal of this paper is to assess what has been published about the future of work to give a foresight on a credible future scenario of the impact on inequalities and evaluate the current capability of the European Union to meet the upcoming challenges. We will conclude with a series of strategic recommendations.

\section{The factors of technological change}

There are two opposing forces that drive the pace of automation. Technological capabilities and willingness to adopt these technologies. We have decided to begin this work explaining these factors because their interplay will determine the speed and magnitude at which our society will transform. It is important to keep them into account during the rest of the work.

On the one hand, we find that technology grows exponentially, which predicts that our society will change faster and more substantially than ever before. On the other hand, we find that companies are reluctant to implement technologies, losers will fight to maintain the status quo, public opinion may drive stringent regulations and it may not be profitable for businesses to implement all existing technologies.

\subsection{Exponential Technological Change}

In 1965, Gordon Moore, founder of Intel, observed that the number of transistors per square inch on a minimum-cost integrated circuit had doubled every year since their invention (Moore, 1965). Up until today this trend has been maintained, as in the last 50 years, the number of transistors (a proxy for computational power) in microprocessors has doubled every 18 months (Encyclopædia Britannica, 2018). The same progress has been documented for disk drive capacity, display resolution and network bandwidth (Brynjolfsson \& McAfee, 2011).

The legend of the invention of chess is a good metaphor to understand exponential growth. In one version of that story, an emperor had promised to grant any wish to whomever would make his daughter smile. She smiled at the game of chess so the inventor was granted a wish. He requested to have one grain of rice in the first square of his chess board, 2 on the second, 4 on the third, and so on. The request was immediately granted. And the story ended with:

The emperor going bankrupt because the doubling of grains of rice for each square ultimately equaled 18 million trillion grains of rice. At ten grains of rice per square inch, this requires rice fields covering twice the surface area of the Earth, oceans included. (Kurzweil, 1999, ch.1)

Since 1958 was the first year that "Information Technology" was a category of business investment in the US and 18 months is Moore's Law standard doubling period; in 2018 we are only in square number 36 out of 64 , and just about to experience game-changing acceleration of technological inventions (Brynjolfsson \& McAfee, 2011). 
Nothing suggests that technological progress will slow down, indeed, with the universalization of education and demographic growth, today there are more people than ever, more educated than ever, focused on delivering innovative solutions to world problems.

Let's look at things in perspective. Britain was the first country to industrialize, and they needed 154 years to double output per person, with a population of only 9 million. The United States came next and took 53 years to double their per capita output. China and India needed 12 and 16 years, respectively, with over 100 times more population. Today's economic acceleration is therefore "roughly 10 times faster than the one triggered by Britain's Industrial Revolution and is 300 times the scale —an economic force that is 3,000 times as large" (Dobbs et al., 2015, p. 21).

When we assess the speed of technological progress, we also need to take into account the potential of major technological disruptions that we cannot even conceive today. Nassim Nicholas Taleb's Black Swan Theory (Taleb, 2007) explores the existence of unpredictable events that have extreme impacts. His recommendation is to build robust strategies based on identifying potential vulnerabilities. As we will see in following sections, growing inequalities are one of the vulnerabilities of today's society.

Let's remember that the internet started to be commercialized in 1996, the first implementation of blockchain technology happened in 2009, and the explosion of 3D printing technology has only started about 5 years ago. Who knows whether in the next decades, scientists at the ITER experiment will achieve the production of affordable nuclear fusion energy. Or what will happen when and if quantum computers, which Google claims are 100 million times faster than traditional computers, become fully operational? (Nguyen, 2018).

\subsection{Social and Economic Obstacles}

We have to acknowledge that technical progress will not necessarily be implemented in the short term for economic, regulatory, ethical or social reasons. Let's have a look at former social resistance to technological progress. It is always useful to look at the dynamics of the former industrial revolution.

\subsubsection{The Fight to Maintain the Status Quo}

In the 16th century, William Lee was determined to create a machine that would free people from hand-knitting. In 1589, his "stocking frame" machine was finished, and he sought a patent from Queen Elisabeth I. Her response was devastating: "Thou aimest high, Master Lee. Consider thou what the invention could do to my poor subjects. It would assuredly bring to them ruin by depriving them of employment, thus making them beggars" (Acemoglu \& Robinson, 2012, ch. 7). The idea behind this story is that although creative destruction is overall positive for society, it threatens the livelihood of those who work with the old technologies, and those people will fight to maintain the status quo.

Without inclusive growth, to-be losers of technological progress will fight against the implementation of the new technologies. This is what happened in the UK in the 18th Century, when the Luddites protested against the new machines that destroyed employment. The English Parliament passed a law in 1769 punishing the destruction of machinery with death. The 1779 Lancashire riots were suppressed by the army. The British government 
deployed 12,000 men against the Luddite rioters, ending them with hangings and deportations (Mokyr, 1992).

We have seen more recently examples of resistance that somehow resemble the struggles of the artisans some centuries ago. Taxi drivers are organizing to shut down Uber, a technological company that has disrupted the sector through the use of technology. Although unrelated to technological progress, we also had examples in the aftermath of the financial crisis of people demonstrating violently to maintain their acquired rights. Greek police used more than 4,600 teargas capsules in just a week to fight demonstrators (Margaronis, 2008).

These and other expressions of resistance make total sense in a world with limited social protection. But in the light of upcoming technological breakthroughs, they raise the question of whether it would not be more efficient to raise social protection to soften social resistance to technological change. We need inclusivity to have sustainable growth because, otherwise, those left behind will stand on the way of innovation. The OECD suggests this by saying that "promoting inclusiveness is key to stronger and more sustainable productivity growth” (Ramos \& Mann, 2017).

On the corporate side, incumbent industries will also fight to maintain the status quo through practices such as lobbying for protectionist regulation. For instance, Spanish prosumers ${ }^{6}$ of solar energy used to be charged fees for producing energy for their own consumption when they are connected to the grid (Fajardo \& Talaverano, 2018, p. 12). This policy ended after the European Parliament condemned the practice, protecting self-consumption and sale of the surplus in its recent amendments to a Directive proposal from the European Commission (EP, 2018).

There are three mechanisms to prevent incumbents from obstructing technological change: competition policy, restrictions to lobbying and regulation-induced innovation.

Market liberalization and competition policy have arguably dynamized European markets, leading to lower prices and an increase in the amount of companies (EC, 2015, pp. 84-117). However, it is also true that there has been a secular trend of increasing market share concentration, profitability and returns on invested capital; decreasing entry and labor market dynamism, and an increasing number of mergers and acquisitions. Policy makers should be cautious with market concentration because incumbents love to maintain their power ${ }^{7}$.

Lobbying is a phenomenon in which different interest groups defend their interests, something that could be thought to be legitimate. However, it has been argued that lobbying is the mechanism that firms resort to when the development of a country is too high to allow for bribing (Harstad \& Svensson, 2007). The problem with lobbying is that different interest groups have different resources and therefore some views are going to be represented more strongly in policy-making, undermining democracy and economic innovation (Lundy, 2017).

6 Consumers and producers.

7 Recent research points that Horizontal Shareholding may be behind these trends. When a common set of investors own significant shares of competing companies, their incentive is to reduce competition between firms. This phenomenon is omnipresent in the economy and is allegedly behind increasing economic inequalities, slow output and employment growth and higher prices (Elhauge, 2016). 
The European Ombudsman has issued a number of suggestions to improve lobbying practices in the European Union. For instance, improving the transparency register, a list of dos and don'ts and a direct call to former European Council President to "consider publishing information about meetings he and his cabinet hold with interest representatives" (European Ombudsman, 2017). It is in the interest of technological progress and growth that these suggestions are followed.

Finally, and contrary to widespread beliefs, regulation can trigger innovation (Mazucatto, 2013). With highly stringent regulations, outsiders come in and revolutionize the market. Without strict regulations, incumbents stay indefinitely in the market. The sort of regulation that is needed should be stringent enough so that compliance is very expensive with existing technologies, it requires the development of new technologies and it requires a dramatic change (Ashford, 2018).

We therefore have two forces that try to maintain the status quo, corporations and citizens. Corporations will try to maintain their market share, and people will fight to maintain their livelihoods. There are three methods to keep incumbent corporations from obstructing the adoption of new technologies. But there is one golden method to prevent citizens or workers from standing on the way of innovation. That method is to redistribute the benefits from technological progress.

Frey and Osborne summarize this problematic well:

Workers can thus be expected to resist new technologies, insofar that they make their skills obsolete and irreversibly reduce their expected earnings. The balance between job conservation and technological progress therefore, to a large extent, reflects the balance of power in society, and how gains from technological progress are being distributed. (Osborne \& Frey, 2013)

Thus, the bottom line is that societies which do not engage in active redistribution of the benefits of automation, will face bigger resistance to its adoption. Bill Gates may have got it right when he stated:

It is really bad if people overall have more fear about what innovation is going to do than they have enthusiasm. (...) And, you know, taxation is certainly a better way to handle it than just banning some elements of it. (Delaney, 2017)

\subsubsection{Public Opinion}

There may be other sources of resistance to innovation. After the fatal accident of an Uber self-driving car in March 2018, Andrea Renda wrote on Forbes that "emerging disruptive technologies need to gain the acceptance of end users before being fully deployed on the market" (Renda, 2018). Otherwise, more accidents could lead to decreased consumer trust and a much slower adoption of the technology due to political reasons.

It would not be the first time in history that a technology stops its development due to social opposition. In the 1930s, airships were "whisking well-to-do passengers across the Atlantic Ocean, and were considered a technological marvel" (Reed, 2015). However, the Hindenburg crash in 1937 abruptly stopped any developments in the industry. There are 
other technical and economic reasons why airships did not succeed, but the lesson learned from that disaster is that public opinion shapes technological progress and implementation.

Another interesting case of slow technological adoption is the case of Genetically Modified Organisms. Although considered to be harmless by most scientists, according to a 2010 Eurobarometer, 61\% of Europeans were opposed to the development of GMO food in Europe (Eurobarometer, 2010).

A reason given by Sylvie Bonny in a paper published at the National Institute of Agricultural Research of France, is the following:

Public opinion was strongly marked by various issues, especially contaminated blood (HIV), Mad Cow disease, asbestos, and so on. These issues led to strong distrust and caused the public to believe that firms and public authorities sometimes disregarded health risks to protect economic or political interests. (Bonny, 2003)

The take-away from these three episodes is that, even though technical capabilities may seem promising, the actual rate of adoption of new technologies will depend on the way their development is undertaken, so that very likely society will need time to accept certain developments, slowing down the commercial adoption of new technologies.

\subsubsection{Sluggish Adaptation}

Another reason why technological capabilities may not accurately predict job automation is the industry's sluggish adaptation to innovation. It may be a consequence of the principle that 'if it is not broken, do not fix it', but very often industry is not up to date with technological change. One example comes from Germany's 'Industrie 4.0' initiative which aims to "drive digital manufacturing forward by increasing digitization and the interconnection of products, value chains and business models" (European Commission [EC], 2017a, p. 3).

Initiatives such as this one demonstrate that industry needs a push when it comes to utilizing existing technologies. What is more, according to a survey among German firms by ZEW, only $4 \%$ of German firms are participating or about to participate in this kind of projects and only 18\% know about their existence (ZEW, 2015).

Other reasons why the adoption of technology may be hindered are the potential preferences to have certain tasks undertaken by humans, such as nursing or caring activities; and a potential shortage of qualified personnel to handle these new technologies (Arntz, Gregory, \& Zierahn, 2016)

\subsubsection{Economic Reasons}

The final reason why labor may be preferred over technology is economical: wages may be relatively cheaper than the price of new technologies. However, let us recall Wright's law of technological progress (Chandler, 2013). This theory posits that costs in any given industry decrease as cumulative production increases. The consequence of this phenomenon would be that as time goes by, technology prices would decrease and therefore rational economic reasoning would lead to the adoption of the new technologies. 
Wright's law was hindcasted by MIT researchers and found to be really accurate (Nagy, Farmer, Bui, \& Trancik, 2012). The two components of the relentless decrease in costs are the learning curve and economies of scale. This finding suggests that the price of new technologies is going to decrease exponentially as it starts to be implemented industry-wide.

We can corroborate the theory with empirical data. In 2016, 294,312 units of industrial robots were sold, a 16\% increase from 2015 and a new peak for four years in a row (IFR, 2017). As sales increase, costs decrease. A forecast using Wright's law predicts that industrial robots will cost about 10,800 dollars in 2025, as compared to 67,656 in 2005 (Korus, 2017). Just for the interest of the law and its prediction with real data, I am attaching the figure here.

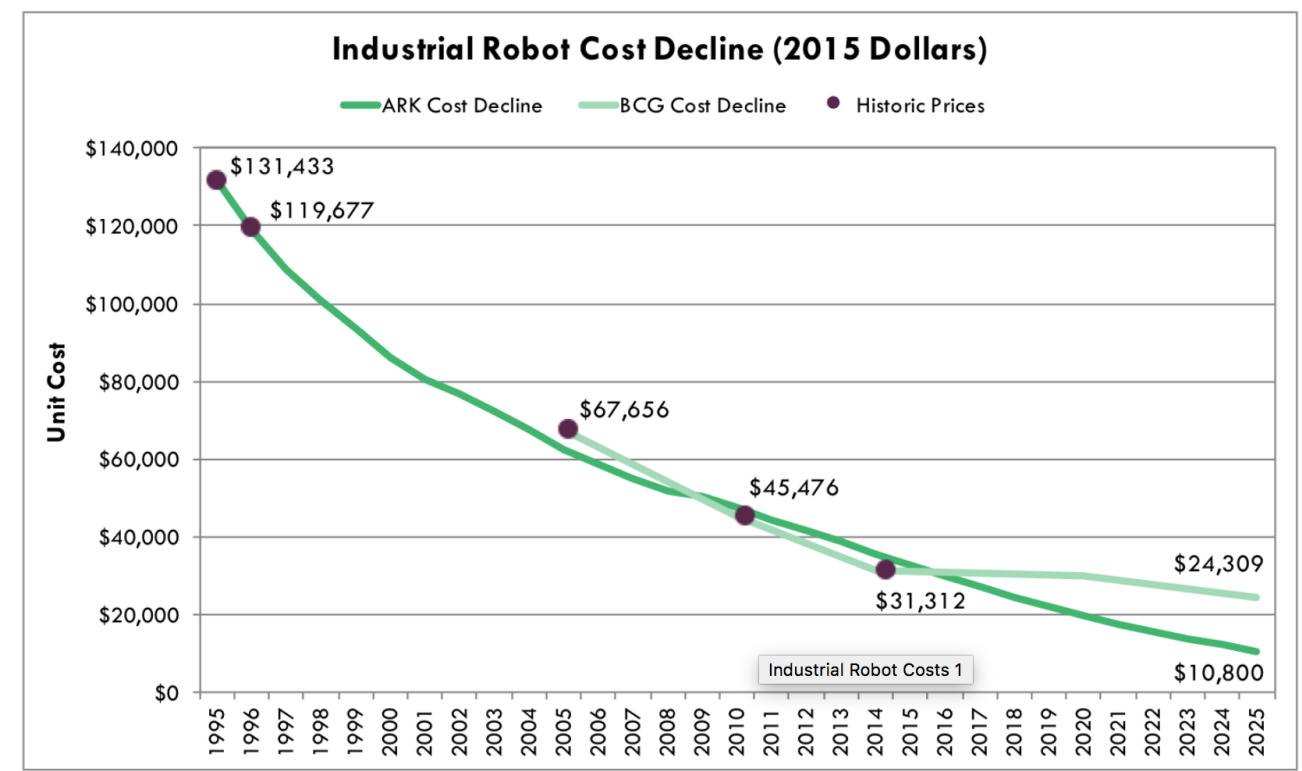

Source: ARK Investment Management LLC | ark-invest.com

Another argument to support the prediction that there will be a substitution from labor to technology comes from the marginal productivity economic theory, which suggests that wages will increase to the same extent than labor productivity does ${ }^{8}$. "To the extent that the new technologies complement workers, labour productivity increases. This may lead to either higher wages, or higher employment" (Arntz et al., 2016, p. 24). Nevertheless, as we will discuss later, it seems as though, in the last few decades, there has been a decoupling of productivity growth and wage growth, with the share of national income captured by labor having declined significantly (Karabarbounis \& Neiman, 2014). If this trend continued, we could expect a slower pace of the adoption of technology, given that cheap labor would continue to compete with technology prices. Anyhow, with secular decreases in technological prices and increases in technological performance, it seems inevitable that at some point not too far away, these new technologies will be fully implemented.

8 Of course, this theory assumes at least perfect competition in the product and in the factor markets, homogeneity, substitutability and divisibility of factors, and profit maximization. In practice, these assumptions do not hold perfectly so this theory should be used as an intuition. 


\section{The impact on labor markets}

Work is a central pillar of our society. Unemployment is associated with higher mortality and with higher risk of poor mental and physical health (Marmot, 2010, p. 20). Ensuring low unemployment is therefore a top priority of any policy maker.

In this chapter, I am going to explore which type of tasks humans perform and which can be automated. I begin with a review of the existing literature on forecasted employment trends. Then I look at historical experiences and compare them with the current situation. I then turn to analyze examples of new technologies that are substituting for human labor. Finally, I analyze the potential of technology to complement labor and potential sources of new employment in the future.

\subsection{Literature review on the impact of automation on jobs}

The big question that remains to be answered, or rather, that cannot be answered, is whether automation will bring about technological unemployment or whether it will have a positive net effect on employment.

There is broad consensus in the literature regarding the unprecedented scope of the transformation that we are undergoing. There is also a general agreement that the skills needed in the future will be different and that inequalities will be exacerbated. However, there is disagreement about the net effect it will have in employment. Let us corroborate this claim with the literature.

The OECD paper on the topic (Arntz et al., 2016) reads that "the likely challenge for the future lies in coping with rising inequality and ensuring sufficient (re-)training especially for low qualified workers" (p. 4), however, in their opinion only 9\% of jobs in OECD countries are automatable. They bet on task restructuring and slow adoption of technologies.

McKinsey's report on workforce transition (Manyika et al., 2017) also agrees that "3 to 14 percent of the global workforce will need to switch occupational categories. Moreover, all workers will need to adapt, as their occupations evolve alongside increasingly capable machines" (p. vi).

Germany is the only EU country they analyze. As we can see in the following figure, they also find that those with less education and lower wages will be more affected by automation, effectively widening the inequality gap if no response is undertaken. 
Job change by education and wage level, 2016-303 (midpoint automation)

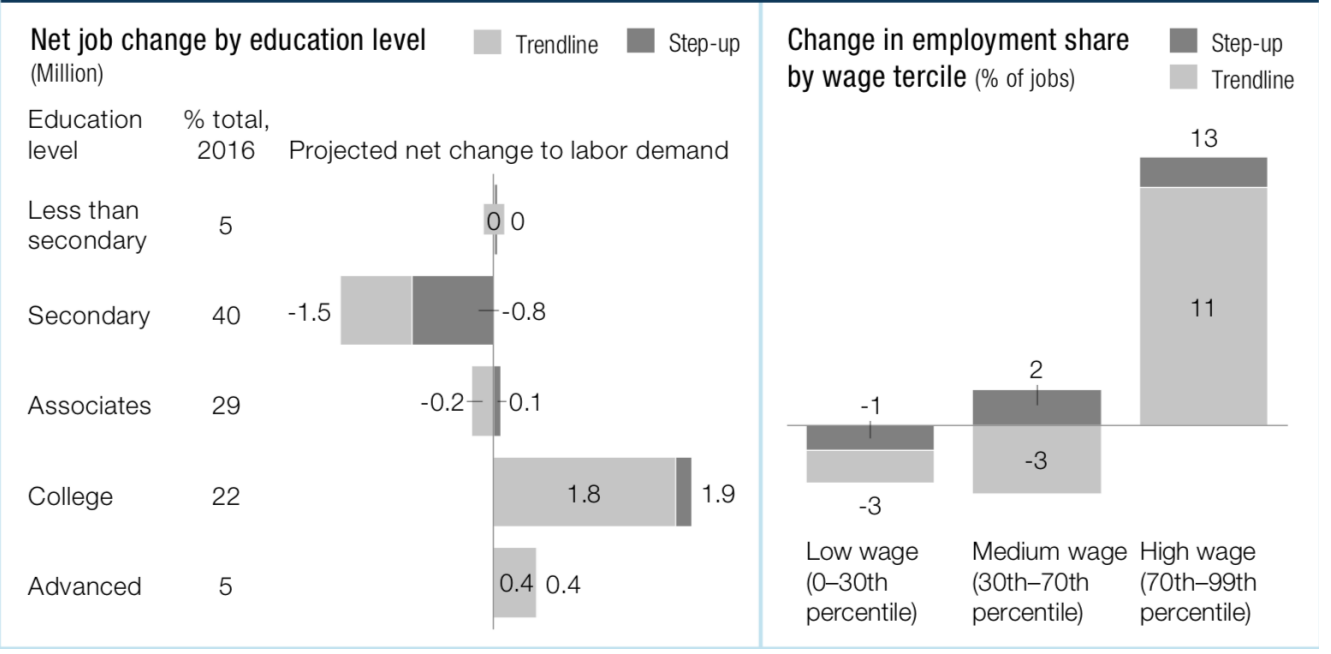

*Source: McKinsey's report on workforce transition (Manyika et al., 2017, p. 95).

However, their forecast of effective job automation differs:

While about half of all work activities globally have the technical potential to be automated by adapting currently demonstrated technologies, the proportion of work actually displaced by 2030 will likely be lower because of technical, economic, and social factors that affect adoption. Our scenarios across 46 countries suggest that between almost zero and one- third of work activities could be displaced by 2030. (Manyika et al., 2017, p. vi)

CEPS's policy insight (Pupillo, Noam, \& Waverman, 2018) concludes that the internet has brought about labor market inequalities and job polarization that will not be solved by themselves. However, for them "it is not clear if more jobs are created than are destroyed" ( $p$. $13)$.

Frey and Osborne from Oxford also agree that "computerisation will mainly substitute for low-skill and low-wage jobs in the near future" (Frey \& Osborne, 2013, p. 42), but in their view up to $47 \%$ of all US jobs are at risk of automation.

There are different reasons for the different assessments. In the first place, because some authors focus on past trends that are catching up with us to forecast the future, whereas other authors open up the blinders and explore phenomena that is coming at us.

For instance, while McKinsey bases its analysis on "adapting currently demonstrated technologies" (Manyika et al., 2017, p. 28), Frey and Osborne's predictions are based on "expanding the premises about the tasks that computer-controlled equipment can be expected to perform" (Frey \& Osborne, 2013, p. 42).

Another reason is the different interpretation of future labor market utilization of the technologies. Frey and Osborne, for instance, ascertain that "it is largely already technologically possible to automate almost any task, provided that sufficient amounts of data are gathered for pattern recognition" (p. 23). So, for them, the amount of future automation is every- 
thing that is technologically possible to be automated today plus a function of the speed in which we are able to overcome what they call "bottlenecks", i.e, those tasks that cannot be performed well by computers today and nor they are expected to be performed well in the near future. Those bottlenecks are creative, social intelligence, and perception and manipulation tasks.

The OECD paper, instead, argues that "even if new technologies are introduced, workers can adjust to changing technological endowments by switching tasks" (Arntz et al., 2016, p. 4). In their model, only those jobs that have more than $70 \%$ of tasks that can be automatable in the near future are categorized as "high risk". The assumption is that workers will concentrate on "bottleneck" tasks. For instance, those that "require cooperation with other employees or where people spend more time on influencing others" (p. 15).

Both methods can be criticized: it is difficult to believe that employers will eradicate complete jobs even if there are promising new technologies. There is evidence of task-shifting in the past. For instance, the within-industry shift from routine tasks to nonroutine tasks accelerated commencing in the 1970s (Autor et al., 2003), and we should expect that in the future too. Also, as we already mentioned, mantras such as the "if it is not broken do not fix it" or fear to change the way business is done will very likely slow down the pace of automation adoption.

However, it is hard to believe as well that although $36 \%$ of tasks are automatable in Estonia, as we can see in the next table, only $6 \%$ of their jobs are at high risk. Even if workers switch to undertake more social and creative tasks, I would argue that, to a certain extent, employers will probably find a way to restructure these "human" tasks in new more "human" jobs, thus saving on labor and increasing profits. 
Table 4. Automatibility by OECD Countries

\begin{tabular}{|c|c|c|c|}
\hline Country & $\begin{array}{c}\text { Share of } \\
\text { People at High } \\
\text { Risk }\end{array}$ & $\begin{array}{l}\text { Mean } \\
\text { Automatibility }\end{array}$ & $\begin{array}{c}\text { Median } \\
\text { Automatibility }\end{array}$ \\
\hline Austria & $12 \%$ & $43 \%$ & $44 \%$ \\
\hline Belgium & $7 \%$ & $38 \%$ & $35 \%$ \\
\hline Canada & $9 \%$ & $39 \%$ & $37 \%$ \\
\hline Czech Republic & $10 \%$ & $44 \%$ & $48 \%$ \\
\hline Denmark & $9 \%$ & $38 \%$ & $34 \%$ \\
\hline Estonia & $6 \%$ & $36 \%$ & $32 \%$ \\
\hline Finland & $7 \%$ & $35 \%$ & $31 \%$ \\
\hline France & $9 \%$ & $38 \%$ & $36 \%$ \\
\hline Germany & $12 \%$ & $43 \%$ & $44 \%$ \\
\hline Ireland & $8 \%$ & $36 \%$ & $32 \%$ \\
\hline Italy & $10 \%$ & $43 \%$ & $44 \%$ \\
\hline Japan & $7 \%$ & $37 \%$ & $35 \%$ \\
\hline Korea & $6 \%$ & $35 \%$ & $32 \%$ \\
\hline Netherlands & $10 \%$ & $40 \%$ & $39 \%$ \\
\hline Norway & $10 \%$ & $37 \%$ & $34 \%$ \\
\hline Poland & $7 \%$ & $40 \%$ & $40 \%$ \\
\hline Slovak Republic & $11 \%$ & $44 \%$ & $48 \%$ \\
\hline Spain & $12 \%$ & $38 \%$ & $35 \%$ \\
\hline Sweden & $7 \%$ & $36 \%$ & $33 \%$ \\
\hline United Kingdom & $10 \%$ & $39 \%$ & $37 \%$ \\
\hline United States & $9 \%$ & $38 \%$ & $35 \%$ \\
\hline
\end{tabular}

Source: Authors' calculation based on the Survey of Adult Skills (PIAAC) (2012)

*Source: Autor et al., 2003, p. 33.

The conclusion from the literature review is that there is too much disagreement about the specific impact that automation will have on jobs to use those forecasts to guide policy action. It is better for policy makers to take action where there is a certain amount of consensus: the need for educational reform and for improved social protection. This will be the content of the last section of this article.

\subsection{Understanding task automation}

We need to define what can be automatable. A fundamental piece of research on this issue was done by Autor, Levy and Murnane in 2003. They conceptualize "work" as a series of tasks to be performed. These can be anything, for instance moving objects, performing calculations, communicating pieces of information or solving problems.

Computers can "rapidly and accurately perform repetitive tasks that are deterministically specified by stored instructions (programs) that designate unambiguously what actions the machine will perform at each contingency to achieve the desired result" (Autor et al., 2003, p. 1282). These repetitive tasks are often referred to as "routine tasks". The main point to take into account here is that tasks are repetitive inasmuch as we are able to break processes down into simple components that can be performed by machines.

The philosopher Michael Polanyi observed that our "tacit knowledge of how the world works often exceeds our explicit understanding" (Autor, 2014, abstract). What this means is 
that we know how to do things that we do not really understand, so that as we advance our knowledge, we are able to break processes down into more and more automatable tasks.

For instance, whereas driving a car through city traffic was considered a non-routine task in Autor's 2003 paper, it has now been broken down into countless automatable tasks, such as compiling data from different sensors, analyzing it and deciding the course of action. The routinization of tasks is, in a way, overcoming Polanyi's paradox towards the perfect understanding of everything that we do (idem).

These routine and nonroutine tasks can be at the same time manual or cognitive. Manual tasks are those that could potentially be automated through the use of a robot or machine, and cognitive tasks are those that could potentially be automated through the use of a computer or artificial intelligence?

At the same time, the implementation of a new technology can either substitute or complement labor. When tasks are fully implemented by technology, occupations become more capital intensive. There is a substitution effect because with the increase in the demand for capital (the new technology), labor demand decreases. When tasks are performed more efficiently by workers thanks to new technologies, output increases and labor demand may increase. There is a complementarity or capitalization effect because the increase in the demand of capital also increases the demand for labor. The interplay between the substitution and complementarity effect is what determines whether automation will bring a net employment gain or loss in the future as we will see in future sections.

It is useful to remember the historical trend in task automation. The automation of routine manual tasks in the 19th century complemented routine information-processing cognitive tasks. We could see that in the sharp increase of the clerking occupation (Autor et al., 2003, p. 1284).

In the 20th century, computers substituted for the same routine information-processing cognitive tasks that the 19th century had seen rise. Repetitive cognitive occupations such as cashiers, telephone-operators or bookkeepers disappeared (Autor et al., 2003).

Right now, there is a third wave of automation coming, which offers endless possibilities with the combination of machine learning and mobile robotics. I will use the example of machine learning and big data to show how, for the first time, non-routine cognitive tasks are being automated today.

The term machine learning was coined in 1959 when a computer was programmed to learn how to play the game of checkers better than the creator of the program (Samuel, 1959).

The reason why machine learning, data mining and other related data analytics disciplines are becoming popular today, is because of big data. In fact, it is the combination of increasing computational power and increasing amounts of available data that allow programs to recognize patterns and detect trends in a way that humans cannot compete.

\footnotetext{
9 For more comprehensive information regarding how skills are applied in different tasks at work, check the "Programme for the International Assessment of Adult Competencies" of the OECD. http://www.oecd.org/skills/piaac/
} 
Data allows to specify the different contingencies that a program must manage to turn a non-routine task into a well-defined problem (Frey \& Osborne, 2013, p. 15). To put it in a different way, the availability of large amounts of data regarding the performance of one particular activity allows a program to "learn" all the different contingencies that it can encounter.

For instance, a non-routine cognitive task that is performed pretty well today thanks to data is translation. Just a few years ago, translation programs performed quite a poor job. Today, they are able to translate almost perfectly even the most complex sentences. The underlying reason is the availability of enormous amounts of online human translations. All the documents of the United Nations or the European Union which were translated by humans into different languages "taught" the translation programs how to translate so that today they are almost perfect at it.

The revolution of machine learning and big data has just begun. With ever more online communications, sensors and the internet of things, available data is exploding. There is broad consensus that, as a new tweak to Moore's Law, the amount of data available is more than doubling every two years since 2010, and it is expected to continue this trend (Ffoulkes, 2017). To give some perspective, the internet-generated data of 2016 is 199 times bigger than all the words ever spoken by humans and all the information contained in all the books ever written ${ }^{10}$ (Reddy \& Reinartz, 2017, p. 12). And that is not even half of what will be available by the end of this year 2020 .

The bottom line is that an increasing amount of non-routine, cognitive tasks are being performed by computers thanks to their capability of detecting trends and the fact that they do not have cognitive biases. Additionally, an increasing amount of non-routine, manual tasks are being performed by industrial robots thanks to their improved sensors and tools. Finally, as it has already been mentioned, these changes are happening much faster and permeating throughout more occupations than in previous waves of automation, so that the capacity of workers to adapt and switch jobs will very likely be more limited.

\subsection{Less employment? Examples of the substitution or destruction effect}

Although touching on science fiction, Yuval Noah Harari describes very well in chapter 9 of his book Homo Deus what may well be coming in the upcoming decades. He says that in the 21 st Century "humans will lose their economic and military usefulness" (Harari, 2016, p. 362).

On the military domain, he recalls how the trend today is relying on cutting edge technology rather than on limitless cannon fodder. For him, the warfare of the future will be cyberwarfare, with the potential to shut down an entire country in a matter of minutes (p. 365). Indeed, we are seeing already today the birth of hybrid warfare, a mixture of fake news, cyberwarfare, foreign electoral intervention and the use of force. Even for the ethical

10 Own calculation based on the data provided by the author, who references Cisco Systems and the UC Berkeley School of Information. 
use of force, while soldiers kill civilians by mistake, drones equipped with computers with advanced ethical algorithms would ensure better compliance with humanitarian law.

On the economic domain, he points at the decoupling of consciousness and intelligence (p. 368). Until very recently the debate was merely philosophical, but today, although still not conscious, computers are becoming very intelligent. In his view, corporations need intelligence but not necessarily consciousness. Therefore, if a computer is more intelligent than a human, it will obtain the job. Robots and 3D printers will take the manual jobs and highly intelligent algorithms will take the white-collar jobs.

Just a brief recollection of jobs he thinks will be gone: all sorts of driving jobs, manufacturing, bank clerks, travel agents, stock-exchange traders, lawyers, judges, detectives, teachers, doctors, pharmacists... The key lies in two characteristics of computers that make them outperform humans: pattern recognition and lack of cognitive bias ${ }^{11}$. It is not hard to understand why computers may be better fit to recognize patterns when their computing power doubles every 18 months and when they have twice as much data available every two years. Regarding cognitive biases, the old mantra of human rationality has long been rejected by economists, except for some neoclassical economists in danger of extinction ${ }^{12}$. To give a funny example of a cognitive bias, Israeli judges give more favorable rulings after going for lunch (Danziger, Levav, \& Avnaim-Pesso, 2011).

It is often said that computers will never be able to understand human emotions, feelings and personalities. In Harari's view, living organisms are algorithms, so there are increasing ways for computers to decipher even our emotional states. Taibi Kahler, developed a theory of personality called the Process Communication Model. This has been leveraged by the company Mattersight to build a call center filter to allocate customers to agents. The filter listens to the "tone, tempo, keywords, grammar, and syntax" to know what personality type you have and your mood (Lebowitz, 2015). Lebowitz reports a 23\% improvement in call efficiency and $20 \%$ decrease in complaints in just 90 days.

Harari also recollects previous tasks that had been thought impossible to automate but computers eventually proved their competence: facial recognition, chess, the selection of the players of a baseball team, driving, managing and composing music.

Let us have a look now at which jobs are being substituted today. Frey and Osborne (2013) enumerate a great deal of cognitive jobs that risk automation due to computer's ability to detect patterns and judge impartially. To name a few examples, fraud detection has become the domain of computers (Phua, 2010). Cancer diagnosis and chronic care at the Memorial Sloan-Kettering Cancer Center are now being helped by IBM's Watson computer. IBM claims that by 2020 the amount of medical data will double every 73 days, and computes like Watson will be able to "make sense of the overwhelming amount of clinical data, genomic data, and social determinants of health data to find the best path for each patient" (Watson Health, 2018).

11 It is important to note that computers operate with programs designed by people and therefore these programs are also susceptible to some cognitive biases as well.

12 The 2002 Economics Nobel Prize lecture by Daniel Kahneman is very informative regarding cognitive biases. Available at: https://www.nobelprize.org/mediaplayer/index.php?id=531 
In the legal field, new technologies are aiding in a variety of tasks. For instance, smart contracts are on the rise thanks to the blockchain technology and JP Morgan claims that its COIN program extracts and organizes 150 attributes from 12,000 commercial credit agreements in only a few seconds, compared to about 36,000 hours of legal work that it would otherwise require (Son, 2017) ${ }^{13}$. Since Law firms' profits stem from billable hours, it is not clear how these advances will be implemented. We can expect, though, an increase in competition in the sector coming from new players that will try to leverage these technologies to drastically reduce the prices of legal services. This competition will very likely pressure wages down.

Tasks that involve monitoring are increasingly being automatized. Indeed, machines don't have lapses of concentration and sensors are becoming very precise. What in the past meant thousands of hours of watching CCTV footage, is now helped by facial recognition and machine learning. SeeQuestor claims they can quickly "build a wall of faces for everyone that appears in the footage", filter information such as "show me all the males in this video wearing hats / headgear" or even answer questions such as "does this person appear in any of this footage?" (See Questor, n.d.).

Digital monitoring in the health sector is becoming increasingly popular, mainly due to healthcare costs rising to unsustainable levels. Some of the applications relate to Intensive Care Units, where the digital monitoring of integrated biometrics allows for promising predictive alert systems (Clifford \& Clifton, 2012). However, it is the remote provision of physiological data that Clifford and Clifton think will be more disruptive. Remote health monitoring will prove invaluable to assist aid in warzones, quarantined or hazardous regions and remote locations, but it is expected to reduce the cost of managing chronic diseases up to 200 billion in OECD and BRIC countries (Ascari, Bakshi, Grijpink, \& Moss, 2010). A study with 1,963 patients showed that remote health monitoring reduced their health service utilization by $20.7 \%$ (Darkins et al., 2008). We can only guess what these forecast savings in healthcare costs will mean for the future of employment in the sector.

In financial services, high frequency trading and algorithms have been around for some time. These techniques involve AI making investment decisions according to vast amounts of information. Goldman Sachs's Global Core Equity fund was rated as the most profitable in the world with an average annual 13,5\% return over the last 5 years. They use unheard of techniques like satellite images to detect trends in parking occupation or aggregation of internet traffic to estimate visits to companies' websites to forecast revenues (Moreno, 2018). Algorithmic trading is so widespread that the term "flash crash" has been coined to define sharp declines in stock values that take place in a matter of minutes. The exact reason for these crashes is unknown but evidence points towards unexpected interaction between different algorithms. Some of them sell when they read certain news, others sell when they see that other market participants sell, and the whole thing can end up like in 2010 when “investors saw nearly $\$ 1$ trillion of value erased from U.S. stocks in just minutes" (Levine, 2015).

13 For a comprehensive review of 35 current AI applications that help with due diligence, forecasting litigation outcomes, legal analytics, document automation, intellectual property portfolio assessment or e-billing, see Faggella's article "AI in Law and Legal Practice - A Comprehensive View of 35 Current Applications", available at https://emerj.com/ai-sector-overviews/ai-in-law-legal-practice-current-applications / 
Software engineering is one of the fields that seem to be more secure today. But coding is not safe from automation either. Algorithms can already detect bugs in software and optimize parameter and design choices. Evidence suggests that with increasingly big databases of code, one day they will be able to write programs given a number of specifications (Frey \& Osborne, 2013).

AI will also revolutionize the world of education by leveraging insights from neuroscience. One of the ways to improve memorization is to space the repetition of the information, at the beginning at closer intervals and overtime with longer intervals. It has been shown that learning per hour of instruction increases using this method (Kelley \& Whatson, 2013). There is a growing number of applications, such as Memrise, that leverage this and other techniques to enhance learning. With growing learning data compiled from these applications and from Massive Open Online Courses, AI tutors are coming that can get to know your strengths and weaknesses to personalize your learning. One example is the one developed by Mindojo (Mindojo, n. d.).

Computerization of non-routine manual tasks will drive low-skilled workers out of the market. The foremost example is self-driving vehicles, which will very likely have an unprecedented pervasive impact. Not only will truck, taxi and bus drivers become obsolete in the mid to long term, but when the technology is fully implemented, there will be less cars manufactured, affecting the manufacturing, energy, insurance and health care industries (Pupillo et al., 2018). It should be noted that there is high uncertainty about the specific timeline that the implementation of certain technologies like self-driving vehicles will follow. What everyone seems to agree is that in the long-term, the substitution will occur. However, the Boston Consulting Group (2015) forecasts that by 2035, only 15\% of the vehicles will be partially self-driving and 10\% will be fully self-driving. There is time to react, but the change is coming.

The combination of mobile robotics, sensors and machine learning is automating unbelievable tasks. Lettuce compliance with the standards is assessed by a Spanish food processor through measuring its density, so that a robot can take bad lettuce away from the conveyor belt (Frey \& Osborne, 2013). Drones are expected to do infrastructure maintenance, analysis of soils and drainages and delivery of goods and medical logistics, among other tasks, with an expected global market of $\$ 127.3$ billion (Mazur \& Wisniewski, 2016).

In short, the combination of hardware and software, i.e., advanced robotics and artificial intelligence, will have as many applications as human ingenuity can come up with. As the price of technology goes down, its computational capacity increases, impact assessments are carried out, trials and demos are undertaken and there is public opinion acceptance, the market penetration will continue to increase inexorably.

\subsection{More employment? The capitalization or complementarity effect}

The adoption of new technologies does not necessarily lead to job losses. In fact, it raises overall efficiency, potentially leading to higher wages, lower prices, increased consumption and increased jobs (Manyika et al., 2017, p. 55). That's the reason why previous industrial revolutions did not lead to technological unemployment, but rather to shifts in occupations. Until the 19th Century, most people worked in the primary sector, then with the industrial 
revolution most people turned to work in the secondary sector. As technology improved, workers moved away from the secondary to the tertiary sector.

According to the OECD, there are three mechanisms through which employment is created thanks to technological advances (Arntz et al., 2016). In the first place, they create new jobs in new sectors and occupations. For instance, they point out that in 2013, 22\% of new jobs were in the ICT sector. Employment will grow not just in sectors related to the new technological developments, but also in all the fields that implement these technologies. Indeed, as we've discussed in the previous section, we can see the surge in startups that leverage artificial intelligence in all sorts of sectors.

A critique that has been formulated is that the new sectors are more capital intensive and less labor intensive. Whereas General Motors employed more than 800,000 workers and earned \$11 billion in 1979 (adjusted for inflation), Google earned \$12 billion in 2012 but employed about 58,000 people. Whereas Blockbuster earned \$6 billion in 2004 and employed about 84,000 people, Netflix earned \$9 billion in 2016 and employed about 4,500 people (Kurzgesagt, 2017). Indeed, Kurzgesagt, the company that created the video The Rise of the Machines - Why Automation is Different this Time, employs only 12 people but has an audience of millions. In contrast, traditional TV stations employed a much larger share of workers. It can be argued that the internet revolution is creating less jobs than the ones the electricity revolution created.

Secondly, workers become more productive when they use new technologies. A lot of the examples from the previous section can be interpreted as complementing the workers instead of substituting them. Doctors make faster and more accurate judgements, police can make more effective searches of their suspects, call centers deliver a better service, insurance companies operate under less uncertainty and lawyers can avoid repetitive tasks and focus in delivering solutions. Indeed, even if algorithms can detect patterns of fraud better than humans, there is probably enough fraud in the world to guarantee a large labor demand of policemen and detectives to use that information. Likewise, we can expect to have enough crime for policemen to have jobs, diseases for doctors, conflicts for lawyers, complaints for call centers and risks for insurance companies. Thanks to the new technologies, workers deliver solutions faster and become more productive, increasing the size of the economy and driving employment and wage growth. However, labor productivity may not lead to employment growth. From 1998 to 2013, the US economy grew $\$ 4.5$ trillion, adjusted for inflation, a $42 \%$ increase in output. At the same time, population grew by 40 million people. However, the number of hours worked stayed constant at 194 billion (Sprague, 2014). Regarding wage levels, although Graetz and Michaels (2015) find that the use of industrial robots raised wages at the sector level, we already mentioned how there has been a decoupling of productivity growth and wage growth (Karabarbounis \& Neiman, 2014). The European Parliament Research Service mentions that "in 2008 Germany's bottom 90\% had even lower real income than in 1992, according to Thomas Piketty's income database" (Stuchlik, 2015, p. 5).

Thirdly, increased firm competitivity leads to lower costs and prices, driving product demand growth and labor demand growth. A good example of the former argument is the study that shows how computerization generated 11.6 million net jobs across the European Union between 1999 and 2010 (Gregory, Salomons, \& Zierahn, 2015). They show how regions with a high share of automatable tasks gained in competitiveness, increased their income and drove up their demand creating new jobs. According to Graetz and Michaels 
(2015), the introduction of industrial robots in the 17 countries they studied did not have a negative impact in the number of hours worked.

Trends other than technological change may drive employment growth. The McKinsey Global Institute has identified that the world needs \$3.3 trillion dollars annually from 2016 to 2030 to fill infrastructure gaps, but that only $\$ 2.5$ trillion are being mobilized (Woetzel, Garemo, Mischke, Hjerpe, \& Palter, 2016, p. 1). An increasingly older society will require higher investments in healthcare and care-work. Meeting climate change challenges will require vast investments in energy efficiency and renewable energies. Current unpaid work such as cooking, childcare or cleaning could start being paid for (Manyika et al., 2017).

Nevertheless, without changes in current public policy strategy within the EU, we are far from fulfilling these predictions. Without moving towards a fiscal union, reduced fiscal space at the member state level due to the Stability and Growth Pact restricts the amount of investment that can be done. Private investments should not be expected to fund infrastructure easily.

The lack of incentives for interconnector investment in electricity markets has long been documented (Pelkmans \& Kapff, 2010; Bjørnebye, 2006; Talus \& Wälde, 2006). The same has been documented for telecom infrastructure investment. Net neutrality chills investment in infrastructure, that is, the obligation to give access to third parties to one's infrastructure at regulated prices deters incumbent players from upgrading it (Renda \& Yoo, 2015). The big money lies in providing faster content delivery to the big players such as Netflix, Google or Apple. These tech giants are now contracting with companies such as Akamai or Level 3 to use their Content Delivery Networks to effectively bypass net neutrality. The bottom line is that we still have not figured out how to incentivize companies to undertake large investments in telecom infrastructure.

It is unlikely that, given the current trends, there will be enough resources to step up expenditure in third-age care. We have already mentioned that governments are constrained under tight budgets. An alternative for higher third-age expenditure would be private spending. However, there are several factors that suggest that pensions will be smaller in the future. In the first place, it should be noted that pensions are for the most part contributive, meaning that they reflect previous earnings. As we will see in the next section, there is widespread agreement that there will be a workforce transition due to automation, with low-skilled workers likely to suffer long-term unemployment and putting downward pressure on wages. Additionally, there will be increasing income inequalities. Therefore, we should expect a larger share of the population contributing a decreasing amount to their pensions, leading to a reduction in old-age expenditure compared to current pensioners. $63 \%$ of the OECD population does not have higher education (OECD, 2017a, p. 50), and many of these people may face long-term unemployment and low-wage jobs. Given that marginal propensity to consume decreases with income growth (Rhee \& Kim, 2017), the trend leads us towards overall decreased old-age consumption.

We should not expect private savings to complement public pensions, because in most OECD countries, "public transfers provide the bulk of income in the old age" (OECD, 2017b, p. 132). We should not expect either to have member states increasing their pension expenditure as long they are under tight budget control from the EU. The EU does not seem to understand these challenges, when the recommendations that they give to member states in the European Semester 2017 factsheets can be summarized in: encouraging private 
pensions, reducing the non-contributive part to incentivize work and postponing retirement age (EC, 2017b).

The same argumentation is valid for healthcare expenditure. Tight budgets, limited oldage income and new technologies such as the already mentioned remote health monitoring will not guarantee a sustained increase in health-related jobs. Furthermore, the EU recommendations to member states from the European Semester 2017 factsheet are on the same line: Improving the governance of the systems, promoting the sustainability of financing and expenditure and strengthening structural efficiency, competition and transparency (EC, 2017c).

In conclusion, new technologies have two competing effects: on the one hand they increase the marginal productivity of workers, which leads to higher output and wages in technology-intensive industries. But on the other hand, they reduce the demand for undifferentiated labor, which leads to technological unemployment, especially for less-skilled workers. Current evidence suggests that the capitalization effect is dominating the substitution effect for now. This trend is expected to continue in the short-term. For the mid-term, necessary strategic investments and the development and adoption of new technologies should create new jobs that offset those that will be automated. However, trends of increasing inequalities and constrained fiscal space may jeopardize the realization of potential new jobs.

\section{Policy responses to ensure well-being}

\subsection{Asymmetrical impact of automation on education levels}

In the previous sections, we have concluded that there was uncertainty about whether there was going to be a net loss or gain in jobs. But there is widespread agreement that the type of tasks undertaken will change. Low-qualified workers will be affected the most by automation because they perform a higher share of automatable tasks (Arntz et al., 2016, p. 23). For advanced economies, occupations requiring higher education will grow whereas those requiring secondary education or lower will decrease (Manyika et al., 2017, p. 15).

Demand for certain low-skilled jobs will increase, because non-routine manual work in unpredictable environments will be hard to automate. However, process innovations will simplify some of these tasks. For instance, off-site construction or prefabrication allows for large chunks of a building to be created in predictable environments, where robots can largely automate the process. For the rest of manual jobs, excess labor supply for these tasks will pressure wages down so that the polarization between high-paying tech jobs and the low-paying jobs that do not require qualification will accentuate.

The trend in the 19th Century was to substitute high-skilled workers, such as artisans, due to the simplification of their complex tasks in production lines that could be performed by low-skilled workers. In the second half of the 20th Century, it was the middle-skilled workers that were substituted by computers leading to a reduction in many professions such as bookkeepers, cashiers and telephone operators. The novelty in the 21 st Century is that lowskilled and low-wage workers will also be substituted, as 3D-printers take manufacturing jobs, and robots undertake more and more tasks like we have explained in previous sections (Frey \& Osborne, 2013). 
Since low-skilled jobs have lower wages, they will take longer to automate than higher-skilled jobs because of economic reasons. Nevertheless, as we've seen with Wright's Law, the price of technology follows a downward slope. Therefore, in the mid to long run, we can expect a large share of those jobs to be performed by robots.

We need to put these trends into perspective. The percentage of educated people is not very high. In 2016, only 37\% of OECD adults between 25 and 65 years old have higher education (OECD, 2017a, p. 50). It is only slightly better for young people, 43\% of young adults between 25 and 34 years old had a tertiary degree in 2016 (OECD, 2017a, p. 51). That means that 20 years down the line, when the effects of automation that we are discussing in this work are fully fledged, a great deal of those $57 \%$ without a university degree that will be aged between 45 and 54 years old, are going to be in trouble.

The need to reskill workers will be so high, that McKinsey claims that do tackle workforce transition, many countries will need initiatives of the scale of the Marshal Plan involving "sustained investment, new training models, programs to ease worker transitions, income support, and collaboration between the public and private sectors" (Manyika et al., 2017, p. 17). The Marshal Plan, officially the European Recovery Program, had a budget of $\$ 110$ billion, in 2016 US dollars.

However, and as we have seen, the European Commission does not allocate resources to the Key Competences for Lifelong Learning in its Proposal for a Council Recommendation, it tackles inequalities through the voluntary participation in the Open Method of Coordination, it recommends member states to maintain a sustainable and restricted expenditure on healthcare and pensions, and it keeps member states' budgets controlled through the deficit rule. In short, it is difficult to see how we are moving in the right direction when "investments and policies to support the workforce have eroded. Public spending on labor force training and support has fallen in most OECD countries" and "educational models have not fundamentally changed in 100 years” (Manyika et al., 2017, p. 18).

Finally, one word on job prospects for college educated workers. We have focused on the impact on low-skilled workers. However, we have also mentioned that many routine cognitive tasks, and increasingly non-routine cognitive tasks are being automated as well. Additionally, there is an increasing number of college graduates. Both factors taken together are polarizing the world of highly educated workers between those with average grades and average college degrees, on the one hand, and those graduated from selective institutions and those who hold master's and doctoral degrees, on the other hand (Goldin \& Katz, 2008, p. 302).

Given all of the above, the current trend of job market polarization may not be a good predictor of what will happen in the future of work. Those at the upmost part of the spectrum, with rare and valued skills related to artificial intelligence and mobile robotics, will be paid the biggest premiums (Metz, 2017). But those at the lowest part of the spectrum, with routine manufacturing jobs, will very likely be replaced. In the middle, there will be losers and winners of all kinds. Artistic creative activities, associated with medium to low incomes except for prestigious exceptions, will likely see demand and wage growth. On the contrary, higher earners with modest cognitive tasks such as paralegals and back officers will probably see their prospects worsen. Those with excellent people skills or with high empathy but without necessarily holding degrees, which today may be doing medium to 
low paying jobs, will probably fare better in the future. In short, the future will be highly heterogenous, with unexpected winners and losers on all sides of the spectrum.

We can draw some policy conclusions from this section. First, it will be necessary to reskill millions of low-skilled workers, or, alternatively, to support them. This will require very large amount of resources that member states will be unable to raise unless new international mechanisms are adopted to dramatically increase fiscal space.

Second, the skills needed in the future will probably be different than the ones we need today. However, there are reasons to believe that current education systems are not equipping students with many general skills that are necessary to thrive in a volatile, uncertain, complex and ambiguous world. Some of these skills are mindfulness, emotional intelligence, flexibility and adaptability, initiative and self-direction, social and cross-cultural skills, productivity and accountability, leadership and responsibility, creativity and innovation, critical thinking and problem solving, communication, conflict resolution and collaboration. Other skills relate to information and communication technologies, which include accessing and evaluating information, using and managing information, analyzing media, creating media products and applying technology effectively (Partnership for 21st Century Learing [P21], $2007 \mathrm{a}$ and 2007b).

Even if incorporating these 21 st century skills in education is urgent, none of the 10 strategic actions of the $2016 \mathrm{New}$ Skills Agenda (EC, 2016) focus on basic education reform. The revision of the Key Competences Framework is a good step in the direction of "promoting entrepreneurial and innovation-oriented mind-sets" (EC, 2016, pp. 5-6) by fostering the introduction in the curricula of "digital competences, entrepreneurship, critical thinking, problem solving or learning to learn, and financial literacy” (EC, 2016, p. 5).

However, a quick look at the Proposal for a Council Recommendation of the 17th of January 2018 (EC, 2018) confirms how lukewarm the initiative is. It has no allocated financial resources and no impact assessment, because of the "complementary approach of the activities to Member State initiatives, the voluntary nature of the proposed activities and the scope of the impacts expected" (EC, 2018). The EU is adopting a reactionary strategy. It is failing to see the benefits that it would bring putting education at the center of the agenda.

There are a number of problems with reforming educational systems. First, it requires massive investments which are not affordable by most countries in a world of tight public budgets. Second, the benefits of education reform would only be seen in the mid to long term, a time horizon that is difficult to appropriate by politicians thinking about the next election. Third, there is no guarantee that the next government will not undo whichever reform is done. Fourth, it is extremely challenging to reskill large amounts of teachers into a different way of doing things. It is for this reason that support from the European Union to member states would help preparing for the future.

\subsection{The European Union's failure to tackle increasing inequalities}

So far, we have explored how automation will very likely accentuate inequalities, rewarding top performers and condemning low-skilled people. We have mentioned how workforce transition and potential long-term unemployment will very likely pressure wages down and reduce pension contributions so that, ceteris paribus, we can expect smaller pensions in the future. We have also seen how societies that do not redistribute the benefits of innovation, 
are likely to face greater opposition from civil society. Finally, we made the case that the European Union is not taking appropriate action in the field of education.

The goal of this article is to inform policy action at the European level to ensure the wellbeing of citizens in the face of automation. Now that we have a better idea of what is coming, it is good to assess how well are we doing today. We find that the trends that are predicted for the future are already pervasive today. There is therefore no "equality buffer" that we can use to soften the distributional impact of automation.

The main goal of policy making should be to make citizens well. According to an OECD's simple model on subjective well-being, the three sub-components of life satisfaction are income, health and work satisfaction (OECD, 2013, p. 33).

Nevertheless, it has been established that the European society is becoming increasingly worried about unemployment, job insecurity, lack of quality employment, poverty and lack of fair access to public health services (Council of Europe, 2018).

If we look closely at the distribution of health status, we find that:

There is a social gradient in health - the lower a person's social position, the worse his or her health. Health inequalities result from social inequalities. Action on health inequalities requires action across all the social determinants of health. Focusing solely on the most disadvantaged will not reduce health inequalities sufficiently. To reduce the steepness of the social gradient in health, actions must be universal. (Marmot et al., 2010)

If European policy makers want to address their citizen's concerns and wellbeing, they should then be focusing on reducing social inequalities through universal actions. But how well are tackling inequalities? According to the European Commission's Directorate-General of Employment, Social Affairs and Inclusion website:

$24 \%$ of all the EU population (over 120 million people), are at risk of poverty or social exclusion — this includes $27 \%$ of all children in Europe, $20.5 \%$ of those over 65, and $9 \%$ of those with a job. Close to $9 \%$ of all Europeans live in severe material deprivation - they do not have the resources to own a washing machine, a car, a telephone, to heat their homes or face unexpected expenses. $17 \%$ of Europeans live on less than $60 \%$ of their country's average household income. (EC, n. d.)

Poverty is widespread and growing in Europe. Since 1970, income inequality has grown and market wages and productivity have diverged in some advanced economies (Manyika et al., 2017, p. 124). More than 50\% of the population in 18 EU Member States report being "struggling", whereas only 6 Member States have more than $50 \%$ of the population reporting being "thriving" (OECD, 2013, p. 187). Nevertheless, the efforts the European Union allocates to reducing inequalities are far away from those allocated to ensuring fiscal stability or avoiding macroeconomic imbalances.

Whereas sanctions are reserved to those that fail to comply with the deficit rule in the Excessive Deficit Procedure, social policy is the domain of the Open Method of Coordination. This method is based on the subsidiarity principle and amounts to just a "voluntary selfevaluating process, based on common objectives" (EC, 2008, p. 2). 
But even if we know that inequalities are increasing and that the EU limits itself to coordinate Member States in this domain, data shows that social transfers are becoming less effective over time.

In 2010 social transfers in the EU reduced the share of people at risk of poverty from an exante $26 \%$ to an ex-post $16.5 \%$. In 2015 , the ex-ante share of people at risk of poverty was still $26 \%$, but after the transfers there was $17.3 \%$ of the population at risk (EC, $2017 \mathrm{~d}$ ). This means that the amount of people at risk of poverty helped by social transfers was reduced by $8.42 \%{ }^{14}$. This is inappropriate given that the $2010-2015$ period was a time of economic recovery from the great recession.

I find that there is a reluctance to help people in need. This attitude likely comes from the old economic paradigm that redistribution is inefficient and lowers productivity. This view holds that helping the poor is better achieved by directing resources to improving the competitiveness of our economy, so that the increased profits will trickle down to all layers of society. But is this true?

On the domain of health inequalities:

Action taken to reduce health inequalities will benefit society in many ways. It will have economic benefits in reducing losses from illness associated with health inequalities. These currently account for productivity losses, reduced tax revenue, higher welfare payments and increased treatment costs. (Marmot et al., 2010, p. 9)

The International Monetary Fund also acknowledges that inequalities are sand in the motor of growth:

We find that longer growth spells are robustly associated with more equality in the income distribution. For example, closing, say, half the inequality gap between Latin America and emerging Asia would, according to our central estimates, more than double the expected duration of a growth spell. (...). A key implication of these results is that it is difficult to separate analyses of growth and income distribution. (...). Over longer horizons, reduced inequality and sustained growth may thus be two sides of the same coin. (Berg \& Ostry, 2011, p. 3)

We can conclude this chapter by saying that inclusive growth is not only good for the people, but also good for the economy. However, currently, growth is widening inequalities, there isn't a clear strategy to tackle this challenge and automation will only increase the size of this problem. Today, there is a gap of 6 years in life expectancy between rich and poor people $^{15}$. The gap is 13 years if we take into account "disability-free" life expectancy, that is, the expected number of years that we are expected to live without limitations to the activities that we can do (Marmot, p. 10). If we want to prevent moving to a world where some people have very good jobs and live healthily until they are very old, and other people

14 The baseline is $26 \%$ for both years. The difference between both ex-post figures, 17.3 and 16.5 , is $8.42 \%$.

15 Excluding the richest $5 \%$ and the poorest 5\%, otherwise the gap can be as high as 17 years difference in life expectancy. Regarding health expectancy, more than three quarters of the population have less than 68 years old of disability-free life expectancy. The study was undertaken in the UK. 
are either unemployed or have precarious work until they retire with health limitations, then policy action to ensure universal social protection is needed today.

\section{Conclusions}

\subsection{Technological change}

1. The combination of advanced artificial intelligence, robotics and big data will allow in the future to automate virtually any task, whether it is routine or non-routine, manual or cognitive. Only certain social, creative, perception, manipulation or highly-intellectual tasks will not be automated in the next two or three decades. However, the automation of certain tasks does not immediately mean the destruction of jobs, because jobs are composed of many different tasks.

2. These automation technologies have two competing effects. They increase the marginal productivity of workers, which leads to higher output and wages in technology-intensive industries. But they also reduce the demand for undifferentiated labor, which leads to technological unemployment. Evidence suggests that computerization has been a net creator of jobs so far, but exponential growth may change that in the future.

3. Technology grows exponentially, and our society is changing much faster and in much greater scope than ever before. However, there are a number of factors that will slow down the rate of technological adoption in the short term. These factors will give time to policy makers to prepare the workforce transition before new technologies are fully implemented.

4. Factors that slow down progress are the following. Companies may be reluctant to change the way they operate. Wages may be relatively cheaper than technology. Public opinion may be against certain developments. Industry incumbents may lobby to enact regulations that allow them to maintain their power. Workers may resist their substitution if they do not have good social protection.

\subsection{Social implications}

5. There is disagreement about the net effect that automation will have on employment. However, a significant percentage of workers will be displaced, and the majority of workers will need to adapt to new tasks that complement the new technologies. The expected expenditure in workforce transition including retraining and income support will require extraordinary public resources.

6. Low-skilled workers will be the most affected because they perform more automatable tasks and because it is more difficult for them to retrain for new jobs. Workforce transition and potential long-term unemployment will likely pressure wages down. This will lead to an accentuation of the inequalities and poverty that have already been growing in the past decades. 
7. To prepare the future workforce, primary and secondary educational systems should be reformed to include, among other content, 21st century skills, critical thinking, creativity, collaboration and communication. However, appropriate and sustainable public education reform is a very expensive task, as well as technically and politically difficult.

8. Since pensions depend on work contributions, a workforce transition due to automation will ensue a reduced contribution to those pensions. This problem is exacerbated by the current decoupling of labor productivity growth and wage growth. This will reduce the well-being of the elderly.

\subsection{Policy response}

9. Given the difficulties of public education reform noted in point 7 , we recommend the European Union to coordinate a primary and secondary public education reform plan of the scale of the Bologna Plan.

10. The only way to mitigate the inequalities mentioned in point 6 is to ensure employment through public investments and public services and by giving social protection. Both remedies are unlikely to materialize because governments have constrained fiscal capacity to support workforce transition at the member state level. We therefore recommend to the European Union to ensure sufficient fiscal space for social protection, retraining, public services and public investments by further integrating towards a fiscal union and by increasing tax revenues.

11. The European Union, due to the subsidiarity principle, only tackles social affairs through the voluntary Open Method of Coordination. We therefore recommend a treaty reform that confers competences to the European Union in the field of social policies to ensure that minimum standards of social protection are mandatory and monitored by the European Commission.

12. To generate the level of employment recommended in point 10 and given the mentioned difficulties for the private sector to generate adequate level of employment in the midterm, we recommend to the European Union to undertake sufficiently big investments in infrastructure, public services, mitigation and adaption to climate change, care for an aging society and adequate pensions. This recommendation is particularly important as a policy response to point 8 , which means 180 degrees turn from the current recommendations that the European Union gives to member states, which are to reduce the non-contributive part of pensions.

13. Since technological progress increases productivity and is good for society, we recommend the European Union to tackle the challenges of point 4 by mitigating those forces that resist change. Knowledge and Innovation Communities and other similar public initiatives are good steps in fostering the adoption of new technologies among industry participants. The introduction of disruptive technologies such as self-driving cars should be done cautiously to avoid accidents that trigger public opposition. Innovation should be induced through stringent regulations that allow new market players to come in. Lobbying practices should be limited and controlled through increased transparency. 
14. Redistributing the benefits of technological progress will have five benefits: it will soften social opposition to its adoption, it will increase the well-being of citizens, it will make our economies more resilient to the economic cycle, it will revitalize citizens' trust in the European project and it will prevent political instability such as the surge of populism.

\section{Bibliography}

\section{Authors}

Acemoglu, D., \& Robinson, J. (2012). Why nations fail: the origins of power, prosperity, and poverty. London: Profile Books.

Armstrong, S., \& Sotala, K. (2012). How we're predicting AI - or failing to. Tech. Rep. Oxford: Future of Humanity Institute, Oxford University.

Arntz, M., Gregory, T., \& Zierahn, U. (2016). The Risk of Automation for Jobs in OECD Countries: A Comparative Analysis. OECD Social, Employment and Migration Working Papers, 189. Paris: OECD Publishing.

Ascari, A., Bakshi, A., Grijpink, F., \& Moss, P. (2010). mHealth: A new vision for healthcare. London: McKinsey\&Company and GSMA.

Ashford, N. (2018). Regulation-induced innovation. Lecture with PowerPoint at the College of Europe.

Aunión, J. (2013, November 28). 35 años y siete leyes escolares. El País. Retrieved from: https://elpais.com/sociedad/2013/11/26/actualidad/1385489735_160991.html (last accessed, 30/04/2018).

Autor, D. (2014). Polanyi's Paradox and the Shape of Employment Growth. NBER Working Paper $N^{0} 20485$.

Autor, D., Levy, F., \& Murnane, R. J. (2003). The skill content of recent technological change: An empirical exploration. The Quarterly Journal of Economics, 118(4), 1279-1333. doi: 10.1162/003355303322552801.

Berg, A. G., \& Ostry, J. D. (2011). Inequality and Unsustainable Growth: Two Sides of the Same Coin?. IMF Staff Discussion Note, SDN/11/08.

Bjørnebye, H. (2006). Interconnecting the internal electricity market: A goal without a plan? Oil. Gas \& Energy Law, 1.

Bonny, S. (2003). Why are most Europeans opposed to GMOs? Factors explaining rejection in France and Europe. Electronic Journal of Biotechnology, 6(1). doi: 10.2225/vol6-issue1-fulltext-4.

Bowles, J. (2014). The Computerization of European Jobs. Brussels: Bruegel.

Brynjolfsson, E., \& McAfee, A. (2011). Race Against the Machine. Digital Frontier Press. 
Chandler, D. (2013). Researcher finds Moore's Law and Wright's Law best predict how tech improves. Phys.org. Retrieved from: https://phys.org/news/2013-03-law-wrighttech.html (last accessed 15/05/2020).

Clifford, G. D., \& Clifton, D. (2012). Wireless technology in disease management and medicine. Annual Review of Medicine, 63, 479-492. doi: 10.1146/annurev-med-051210-114650.

Danziger, S., Levav, J., \& Avnaim-Pesso, L. (2011). Extraneous factors in judicial decisions. Proceedings of the National Academy of Sciences, 108(17), 6889-6892. doi: 10.1073/ pnas.1018033108.

Darkins, A., Ryan, P., Kobb, R., Foster, L., Edmonson, E., Wakefield, B., \& Lancaster, A. E. (2008). Care coordination/home telehealth: the systematic implementation of health informatics, home telehealth, and disease management to support the care of veteran patients with chronic conditions. Telemedicine and e-Health, 14(10), 1118-1126. doi: 10.1089/ tmj.2008.0021.

Delaney, K. (2017). The robot that takes your job should pay taxes, says Bill Gates. Quartz: Retrieved from: https://qz.com/911968/bill-gates-the-robot-that-takes-yourjob-should-pay-taxes/ (last accessed 01/05/2018).

Dobbs, R., Manyika, J., \& Woetzel, J. (2015). No Ordinary Disruption: The Four Global Forces Breaking All the Trends. New York: PublicAffairs.

Easterlin, R. A. (1974). Does economic growth improve the human lot? Some empirical evidence. Journal: Nations and households in economic growth, 89, 89-125. doi: 10.1016/ B978-0-12-205050-3.50008-7.

Elhauge, E. (2016). Horizontal Shareholding. Harvard Law Review, 109, 1267-1317.

Fajardo, G., \& Talaverano, J. (2018). Wp3: services for prosumers of solar energy. Legal context. Barriers and opportunities. ProSumE: Enabling Energy Prosumers Services.

Ffoulkes, P. (2017). InsideBIGDATA Guide to The Intelligent Use of Big Data on an Industrial Scale. Hewlett Packard Enterprise.

Goldin, C., \& Katz, L. F. (2008). The race between education and technology. Harvard: Harvard University Press.

Graetz, G., \& Michaels, G. (2015). Robots and Work No 8938. IZA Discussion Papers. Institute for the Study of Labor.

Gregory, T., Salomons, A., \& Zierahn, U. (2015). Technological Change and Regional Labor Market Disparities in Europe. Mannheim: Centre for European Economic Research.

Harari, Y. N. (2016). Homo Deus. A Brief History of Tomorrow. London: Harvill Secker.

Harstad, B., \& Svensson, J. (2008). From Corruption to Lobbying and Economic Growth. Working paper. Kellogg School of Management.

Karabarbounis, L., \& Neiman, B. (2014). The global decline of the labor share. The Quarterly Journal of Economics, 129(1), 61-103. doi: 10.1093/qje/qjt032. 
Kelley, P., \& Whatson, T. (2013). Making long-term memories in minutes: a spaced learning pattern from memory research in education. Frontiers in Human Neuroscience, 7, 589. doi: 10.3389/fnhum.2013.00589 (last accessed 01/05/2018).

Keynes, J. M. (1936). The General Theory of Employment, Interest and Money. London: Macmillan.

Korus, S. (2017). Industrial Robot Cost Decline. Ark-invest. Retrieved from: https://arkinvest.com/research/industrial-robot-costs\#fn-23911-1.

Kurzweil, R. (1999). The age of Spiritual Machines. New York: Viking Press.

Lebowitz, S. (2015). Every time you dial into these call centers, your personality is being silently assessed. Business Insider UK. Retrieved from: http:/ /www.businessinsider.com/ how-mattersight-uses-personality-science-2015-9 (last accessed on 30/04/2018).

Levine, M. (2015). Guy Trading at Home Caused the Flash Crash. Bloomberg. Retrieved from: https://www.bloomberg.com/view/articles/2015-04-21/guy-trading-athome-caused-the-flash-crash (last accessed on 30/04/2018).

Lundy, D. (2017). The Corporate Europe Observatory Guide to the Murky World of EU Lobbying. Corporate Europe Observatory.

Margaronis, M. (2008, December 13). How police shooting of a teenage boy rallied the '€700 generation'. The Guardian. Retrieved from: https://www.theguardian.com/world/2008/ dec/13/athens-greece-riotsRetrieved from (last accessed 01/05/2018).

Marmot, M. (2010). Fair Society, Healthy Lives. Strategic review of health inequalities in England post 2010. London: The Marmot Review.

Mazur, M., \& Wisniewski, A. (2016). Clarity from above. PwC global report on the commercial applications of drone technology. PWC, Drone Powered Solutions.

Mazzucato, M. (2013). The Entrepreneurial State: Debunking Public vs. Private Sector Myths. London: Anthem Press.

Metz, C. (2017, October 22). Tech Giants Are Paying Huge Salaries for Scarce A.I. Talent. The New York Times. Retrieved from: https://www.nytimes.com/2017/10/22/technology/artificial-intelligence-experts-salaries.html (last accessed on 30/04/2018).

Mokyr, J. (1992). The lever of riches. Oxford: Oxford University Press.

Mokyr, J. (1993). Creative Forces. Reason. Free minds and free markets. May 1993 issue.

Moore, G. E. (1965). Cramming More Components onto Integrated Circuits. Electronics, 114-117.

Moreno, M. (2018, March 28). Para invertir analizamos por satélite la ocupación de los aparcamientos de Ikea. Cinco Días. Retrieved from: https://cincodias.elpais.com/cincodias/2018/03/26/mercados/1522073179_004863.html (last accessed 01/05/2018).

Nagy, B., Farmer, J., Bui, Q., \& Trancik, J. (2012). Statistical Basis for Predicting Technological Progress. PLoS ONE, 8(2), 52669. doi: 10.1371/journal.pone.0052669. 
Nguyen, L. (2018). The era of quantum computing? Not quite yet. Wikitribune. Retrieved from: https://www.wikitribune.com/story/2018/02/16/technology/the-era-of-quantum-computing-not-quite-yet/49197 (last accessed 01/05/2018).

Pajarinen, M., \& Rouvinen, P. (2014). Computerization Threatens One Third of Finnish Employment. ETLA Brief, 22.

Pelkmans, J., \& Kapff, L. (2010). Interconnector Investment for a Well-functioning Internal Market. What EU regime of regulatory incentives?. Bruges European Economic Research Papers, 18.

Phua, C. (2010). A Comprehensive Survey of Data Mining-based Fraud Detection Research. Intelligent Computation Technology and Automation (ICICTA).

Pupillo, L., Noam, E., \& Waverman, L. (2018). The internet and jobs. CEPS policy insight, $2018 / 06$.

Ramos, G., \& Mann, C. (2017). A Fiscal Approach for Inclusive Growth in G7 Countries. OECD.

Reddy, S., \& Reinartz, W. (2017). Digital Transformation and Value Creation: Sea Change Ahead. Marketing Intelligence Review, 9(1), 10-17. doi: 10.1515/gfkmir-2017-0002.

Reed, D. (2015). Why blimps and airships died out - and how they might make a comeback. Citymetric. Retrieved from: https:/ /www.citymetric.com/transport/why-blimps-and-airships-died-out-and-how-they-might-make-comeback-722 (last accessed 01/05/2018).

Renda, A. (2018). No Need for Speed when it Comes to Autonomous Vehicles. Forbes. Retrieved from: https://www.forbes.com/sites/washingtonbytes/2018/03/20/noneed-for-speed-when-it-comes-to-autonomous-vehicles/\#67b16b6d133f (last accessed $01 / 05 / 2018)$.

Renda, A., \& Yoo, C. (n. d.). Telecommunications and Internet Services: The digital side of the TTIP. Paper No. 8. CEPS-CTR project 'TTIP in the Balance' and CEPS Special Report, 112.

Rhee, D., \& Kim, H. (2017). Does income inequality increase marginal propensity to consume?. Applied Economics Letters, 25(17), 1218-1221. doi: 10.1080/13504851.2017.1412067.

Samuel, L. (1959). Some Studies in Machine Learning Using the Game of Checkers. IBM Journal, July, 210-229.

Son, H. (2017). JPMorgan Software Does in Seconds What Took Lawyers 360,000 Hours. Retrieved from: https://www.bloomberg.com/news/articles/2017-02-28/jpmorgan-marshals-an-army-of-developers-to-automate-high-finance (last accessed 30/04/2018).

Sprague, S. (2014). What Can Labor Productivity Tell Us About the U.S. Economy?. US Bureau of Labor Statistics, Beyond the Numbers, 3(12).

Stiglitz, J. (2012). Elprecio de la desigualdad: el 1\% de población tiene lo que el 99\% necesita. Barcelona: Taurus.

Stuchlik, A. (2015). Wage developments in the euro area. Increasingly unequal?. European Parliament Research Service. 
Taleb, N. N. (2007). The black swan: the impact of the bighly improbable. New York: Random House.

Talus, K., \& Wälde, T. (2006). Electricity interconnectors: A serious challenge for EC Competition Law. Competition and Regulation in Network. Industries, 1(3), 355-390. doi: 10.1177/178359170600100302.

Winter, J., \& Teitelbaum, M. (2013). The Global Spread of Fertility Decline: Population, Fear, and Uncertainty. New Haven, CT: Yale University Press.

Woetzel, J., Garemo, N., Mischke, J., Hjerpe, M., \& Palter, R. (2016). Bridging global infrastructure gaps. McKinsey Global Institute.

Z. E. W. (2015). IKT-Report. Unternehmensbefragung zur Nutzung von Informations- und KommunikationstechnologienOctober 2015, Zentrum für Europäische Wirtschaftsforschung, Mannheim (read in Arntz, M., T. Gregory \& U. Zierahn (2016), The Risk of Automation for Jobs in OECD Countries: A Comparative Analysis. OECD Social, Employment and Migration Working Papers, 189, Paris: OECD Publishing, Paris).

\section{Private organizations}

Boston Consulting Group (2015). Back to the Future: The Road to Autonomous Driving. Retrieved from: http://de.slideshare.net/TheBostonConsultingGroup/the-road-to-autonomous-driving (last accessed 01/05/2018).

Encyclopædia Britannica (n. d.). Moore's law. Encyclopædia Britannica, inc. Retrieved from: https://www.britannica.com/technology/Moores-law.

International Federation of Robotics (2017). Executive Summary World Robotics 2017 Industrial Robots.

Mindojo (n. d.). Making quality education universally accessible and affordable. Retrieved from: https://mindojo.com/about-company.html (last accessed 01/05/2018).

Kurzgesagt (2017). The Rise of the Machines - Why Automation is Different this Time. Youtube video. Retrieved from: https://www.youtube.com/watch? $\mathrm{v}=$ WSKi8HfcxEk\&t=215s (last accessed 01/05/2018).

Partnership for 21st Century Learning (2007a). Framework for 21st Century Learning.

Partnership for 21st Century Learning (2007b). Framework definitions.

Seequestor (n. d.). Products and Services. Retrieved from: https://www.seequestor.com/ \#/productServices (last accessed 01/05/2018).

Watson Health (2018). Watson Health: Get the Facts. Retrieved from: https://www.ibm.com/blogs/watson-health/watson-health-get-facts/ (last accessed 30/04/2018). 


\section{Public institutions}

Council of Europe (2018). The case for a basic citizenship income. Parliamentary Assembly. Doc. 14462.

Eurobarometer (2010). Biotechnology Report. Special Eurobarometer 341. Eurobarometer 73.1.

European Commission (2008). Communication from the Commission to the European Parliament, the Council, the European Economic and Social Committee and the Committee of the Regions. A renewed commitment to social Europe: Reinforcing the Open Method of Coordination for Social Protection and Social Inclusion.

European Commission (2015). Ex-post economic evaluation of competition policy enforcement: A Review of the literature.

European Commission (2016). Communication from the Commission to the European Parliament, the Council, the European Economic and Social Committee and the Committee of the Regions. A New Skills Agenda for Europe.

European Commission (2017a). Digital Transformation Monitor. Germany: Industrie 4.0.

European Commission (2017b). European Semester Thematic Factsheet. Adequacy and Sustainability of Pensions.

European Commission (2017c). European Semester Thematic Factsheet. Health Systems.

European Commission (2017d). Factsheets. Social Scoreboard 2017. Key Findings.

European Commission (2018). Proposal for a Council Recommendation on Key Competences for Lifelong Learning.

European Commission (n. d.). Poverty and social exclusion. DG for Employment, Social Affairs and Inclusion. Retrieved from: http://ec.europa.eu/social/main.jsp? langId=en\&catId=751 (last accessed 01/05/2018).

European Ombudsman (2017). Ombudsman asks President Tusk to publish meetings with lobbyists. Press release11/2017.

European Parliament (2016). Major changes in European public opinion regarding the European Union. Exploratory study. European Parliament Research Service.

European Parliament (2018). On the proposal for a directive of the European Parliament and of the Council on the promotion of the use of energy from renewable sources (recast) COM(2016)0767 - C8-0500/2016 - 2016/0382(COD).

OECD (2013). OECD Guidelines on Measuring Subjective Well-being. OECD Publishing.

OECD (2017a). Education at a Glance 2017: OECD Indicators. Paris: OECD Publishing.

OECD (2017b). Pensions at a Glance 2017: OECD and G20 Indicators. Paris: OECD Publishing. 